\title{
Imagining exodus for Israel-Palestine: reading the secular and the sacred, Diaspora and homeland, in Edward Said and David Grossman
}

\author{
Anna Hartnell, University of London, Goldsmiths College
}

The Palestinians, as is well known, are making use of the ancient Jewish strategy of exile and have removed themselves from history. They close their eyes against harsh reality, and stubbornly clamping down their eyelids, they fabricate their promised land. (David Grossman)

There is no Israel without the conquest of Canaan and the expulsion or inferior status of the Canaanites - then as now. (Edward Said)

The one who merely flees is not yet free; in fleeing he is still conditioned by that from which he flees. (Hegel)

\section{Introduction}

The Exodus narrative functions allegorically in the service of all participants in the Palestinian-Israeli dispute. This paper will concentrate specifically on Israeli renderings of this ancient story. The creation of the state of Israel suspends conceptions of Jewish identity between the tropes of Diaspora and homeland, secular Zionism and religious messianism, and the question of Exodus emerges as a central paradigm through which to examine religion as a major facet in what is often considered to be a predominantly secular Israeli identity. Itself caught in the tension between enacting a gesture of belonging and one of escape, the Exodus narrative calls into question the possibility of its central meaning: a going out, a new departure: exodus.

By conjuring the dream of the 'Promised Land', this biblical myth weaves together national and religious sensibilities and projects them onto the same site. In so doing it links nationhood to an economy of redemption and thus seemingly problematizes those narratives that locate Zionism within a framework of so-called 'Exodus politics’. For can a movement drawing on a discourse of redemption also claim to 
have secularised itself, as Zionism so often states it has done in its particular projection of Jewish identity? Moreover, does the logic of exodus in fact posit secularism as impossible, irrevocably haunted by the religious terms from which it springs and seeks to flee? Does this then mean that 'exodus politics' (Dooley 2001), a term deployed by various postmodernist discourses to indicate a dispersal of meaning, in fact traces the gesture of identitarian recuperation which it claims to hold in abeyance?

The physical return of the Jews to the 'Promised Land' seriously problematizes the current trend in contemporary theory to elevate Jewish identity as exemplary of the fundamentally homeless, exiled identities that inhabit the postmodern world. ${ }^{1}$ And yet perhaps the failure here is less that Jewish identity falls short of this ideal in practice, and more that the theory not only contradicts itself, but also consistently simplifies the profound need and desire for self-determination which proves much more the shaper of national realities than do facile postmodernist theories. The question that this paper will try to examine is; how does religion relate to the tropes of Diaspora and homeland that shape the nature of the Israeli national investment? And specifically, does Judaism serve to support or undo these distinct and often contradictory foundational premises of the Israeli state? If the latter alternative is the case, then perhaps the biblical Exodus narrative is not such an inappropriate symbol of the act of escape to which its name alludes.

This exploration will take place primarily through the writings of David Grossman, whose construction of Jewish identity is envisaged through the regulating, competing and collaborating tropes of Zionism and Diaspora. ${ }^{2}$ Against Grossman’s position, whereby a specifically Jewish 'diasporic consciousness' coexists and reconciles itself with the 'ingathering of the exiles’ (Avineri 1981, 114), I will posit Edward Said’s position which argues for the rigorous distinction between 'secular' and 'religious' cultural affiliations. As Zionism has been Said's natural target of criticism, his work speaks particularly powerfully to the debate surrounding the religious genealogy of

\footnotetext{
${ }^{1}$ This constitutes a large body of scholarship, much of which has taken its cue from the work of Emmanuel Levinas. Specific examples cited later in this paper include Susan Handelman (1982) and Daniel and Jonathan Boyarin (1995).

${ }^{2}$ For the purposes of this exploration I am limited to the use of the English translation of the original Hebrew text: David Grossman, 1999, See Under: Love, trans. Betty Rosenberg, Vintage, London.
} 
Jewish identity. Taking account of Said's distinct and broad interpretation of these crucial categories, I argue that his act of separation, like Grossman’s act of reconciliation, lies on shaky and ultimately questionable grounds.

\section{Exodus as a blueprint for Zionsim: a debate between Michael Walzer and Edward Said}

In 1984 Michael Walzer wrote a book entitled Exodus and Revolution, a book which sparked a bitter dispute between himself and Edward Said over the enduring legacy of the Exodus narrative. Walzer attempts to secularize the biblical text and presents it as paradigmatic for this-worldly revolutionary politics. Said reads this account as a thinly veiled justification for the political positioning of the present-day state of Israel. Commenting on this debate, William Hart suggests that their disagreement encompasses 'not only competing views of how a religious narrative should be represented, but differing views on the nature of secularism' (Hart 2000, 1).

Walzer portrays the Exodus story as one that ultimately envisions liberation, and yet, as Said points out, the narrative seemingly ricochets along the Hegelian dialectic between the figures of master and slave, a movement that seriously questions its supposedly progressive trajectory from oppression to freedom. Said then links this textual tension to that which trammels Zionist thinking. For Said argues that while the Zionist project envisaged freedom for the Jews of the Diaspora within a matrix of nationalism, it did so by taking up the mantel of European colonialism. In an attempt to obliterate the Jew's position as the stateless 'other’ inside Europe, the Zionists created a new condition of statelessness amongst people who constituted an otherness decidedly exterior to Europe: the Palestinian Arabs who populated what came to be known as 'the Land of Israel'. Said thus designates his response to Walzer a 'Caananite reading' (Said 1988), one which pinpoints the exclusions that continue to unfold from the legacy of this religious text.

As William Hart suggests, at the centre of Said's objections lies his desire to re-instate Marx's insistence that 'the premise of all criticism is the criticism of religion' (Marx quoted in Hart 2000, ix). Part of Said's critical project consists in laying bare the fact that the secularising modalities of race, nation, and culture substituted the existential paradigms of religion with new content. While the discursive overlaps between 
nationalism and religion have long been noted, Said advocates continued vigilance to their complicity as different yet complimentary discourses that promote exclusionary narratives of belonging. His consequent notion of 'secular criticism' therefore finds fertile grounds in a text like Walzer's, which appears to justify the existence of a supposedly secular state via a sacred text that explicitly interweaves religious and national sensibilities through the will of a decidedly partial God. Said's primary concern is with Walzer's apparent unconcern for the Canaanites figured in Exodus, who are, as Walzer states without comment, 'explicitly excluded from the world of moral concern' (Walzer 1985, 142). Said complains that 'Walzer offers no detailed, explicit or principled resistance to the irreducibly sectarian premises of Exodus, still less to the notion of a God as sanguinary as Jahweh directly holding them in place' (Said 1988, 167).

Thus at the heart of Said's problematization of the Exodus text lies the idea of 'chosenness', an idea which flagrantly underscores the potentially sectarian nature of religious passions and which Said trenchantly positions himself against. It is what he perceives as religion's nativist bent that leads Said to brand all forms of dogmatism and essentialized identity politics as the products of 'religious thinking' (Said 1983). His critical project thus mobilizes this somewhat radically expanded sense of 'religion' to weed out uncompromising and deeply rooted cultural investments. As a movement which can hardly avoid drawing on the Exodus myth, and whose claim to have severed itself from its religious connections has been precarious at best, Zionism is particularly vulnerable to Said's critique - although, as this paper will attempt to show, perhaps not in quite the way he would have envisaged.

In his book The Making of Modern Zionism: The Intellectual Origins of the Jewish State, Schlomo Avineri claims that 'at the root of Zionism lies a paradox' (Avineri, 1981, 3), one which specifically relates to the somewhat anomalous relationship between Jewish identity and the notion of secularism. He writes:

what singled the Jews out from the Christian and Muslim majority communities in whose midst they have resided for two millennia was not only their distinct religious beliefs but also their link - tenuous and nebulous as it might have been - with the distant land of their forefathers. It was because of this that Jews were considered by others - and considered themselves - not only a minority, but a minority in exile (Avineri 1981, 3). 
And yet there was 'on the one hand a deep feeling of attachment to the Land of Israel, becoming perhaps the most distinctive feature of Jewish identity; on the other hand, a quietistic attitude toward any practical or operational consequence of this commitment' (Avineri 1981, 4).

In other words, it took a secular Jewish movement to actualise the return to the land that religious Jews believed had been promised by God. This was because the practice of Judaism had become so geared towards accommodating life in exile that Jewish religious thought had also developed 'a very strong scepticism about any active intervention in the divine scheme of things. Divine Providence, not human intervention, should determine when and how the Jews will be redeemed from exile and returned to Zion' (Avineri 1981, 4). Those who emerged as prominent Zionist leaders did not on the whole come from traditional religious backgrounds, and it was left to figures like Rabbi Kook to reconcile religious Jews to what some saw as blasphemous Zionist aspirations, by undertaking 'a radical interpretation of the whole religious tradition in order to turn a passive religious messianic hope into the basis for collaboration with an activist political secular movement’ (Avineri 1981, 189).

Having recognised this marked schism between Jewish religious and nationalist sensibilities, Avineri goes on to discuss why it was that this dream of a return to Jerusalem, a dream that had remained dormant - apart from the occasional stirring of a messianic movement - for eighteen centuries, became a force for action in the latter half of the nineteenth century. Explanations relating Zionism to the Jewish spiritual link with 'the Land of Israel' clearly fail to account for this specific historical moment. And yet the most commonly proposed argument attributing Zionism to a heightened anti-Semitism also ignores the fact that Jews had been persecuted for centuries and, moreover, Zionism appeared at a time when Jewish communities were emerging as major beneficiaries of the Enlightenment and religious emancipation. It was in fact the new complexities opened up by religious emancipation, Avineri suggests, which largely created Zionism.

Avineri argues that it was the principles of equilibrium and apartness that, in spite of the 'occasional and horrifying breakdown, enabled the Jews to survive in a basically hostile environment' (Avineri 1981, 8). Post-emancipation, Jews did not easily slide 
into the secular identities imagined for them by modern liberalism. A whole host of cultural rituals such as observance of the Sabbath presented everyday dilemmas even to the most secular of Jews. Moreover, Jewish cultural visibility prevented them from easily allying themselves with the various national groupings that emerged alongside liberalism and secularism in post-Enlightenment Europe. As the Dreyfus Affair highlighted, Jews were seen first and foremost as Jewish rather than French, English etc, and so the first to be named 'Judas' when issues of loyalty to the nation arose (Avineri 1981, 11).

Zionism was thus born as a movement of national self-determination for the Jewish people at a time of burgeoning nationalism in Europe; it was not simply a reaction to persecution, neither was it the culmination of religious hopes to return to Zion. Zionism was necessarily secular as it is in many ways conflicted with Judaism, yet it arose out of a perception amongst some Jews that Jewish communities - so marked out by signs of religious observance - would never properly reconcile themselves, nor be seen to be reconciled to, the secular conditions of modern Europe. Going back to the debate between Edward Said and Michael Walzer, in the light of what is perhaps the unique place of religion within Jewish identity, Said's objections to Walzer's project in the name of 'secular criticism' call for some scrutiny. In defence of his textual leap from the sacred to the secular, Walzer writes: 'Judaism intersects with and partly determines the culture of the Jews. The religious tradition is a battleground and since I am concerned about the outcome, it makes sense to join the battle' (Walzer in Hart 2000, 191). This response suggests that Said's notion of secularism is not adequately inflected with an awareness of Jewish cultural difference. And perhaps it cannot therefore deal persuasively with the conflicted terrain that is the Jewish encounter with the 'secular'.

The somewhat anomalous relationship between Judaism and the notion of the 'secular' is illuminated by Nietzsche's genealogy of secularism, which explicitly identifies it with that of Christianity. As Nietzsche's writing shows, the tenets of liberalism and secularism were the offspring of Christian civilization; there is an internalising movement within Christianity that survived the death of god by crowning the modern subject in the figure of Western man (Derrida 2002, 40-102). And as Derrida points out, the Kantian thesis, which claimed the possibility of a 
'religion within the limits of reason alone' - one based on liberating a reflecting faith in fact stipulated that the subject 'act as though God had abandoned' him. 'The moral law inscribes itself at the bottom of our hearts like a memory of the passion' and 'when it addresses us, it either speaks the idiom of the Christian or is silent' (Derrida 2002, 50). That this idiom was haunted by the traces of Hebrew from which it originated made the Jewish presence in Europe a continual affront even after the socalled religious Emancipation.

Religious ‘freedom' therefore presented itself as a highly qualified category in a language steeped in the terms of covenantal responsibility, one supposedly addressed directly to God. As Derrida asks, 'how can one translate, in the sacred Hebrew or in the semantics enjoined by it, the word Verweltlichung? What is the Jewish equivalent for the spiritual/worldly, sacred/secular opposition, etc? Is there such an equivalent...'? (Derrida 2002, 220). Derrida uses the German word for secular here as he is discussing a letter written - in German - by Gershom Scholem to Franz Rosenzweig, in which Scholem 'confesses' his concerns over the so-called secularisation of Hebrew, the sacred language. Scholem's letter vividly demonstrates that Jewish immigrants to the promised land did not escape the complexities presented to them by the somewhat culturally alien notion of secularism that had confronted them in the Diaspora and which had hastened their departure. As developments in modern Hebrew literature show, the secular signs that elaborated European ideas of nationhood followed the Jews to Palestine. Nowhere is this vexed Jewish cultural tension between the sacred and the secular, divine providence and human agency, more pronounced than in the sphere of language.

To return momentarily to Said and the colonial comparison, it is perhaps possible to see in the Zionist assumption of agency - somewhat ironically - the 'religious-cultural effects' of a tradition looking more like Christianity than Judaism. As Scholem writes,

it is the Christian conviction regarding the redemption which has already come that lends this activism a special seriousness and its special vehemence - and thus its significance in world history. In the Jewish realm, from which it originates, this activism remains singular and strangely powerless precisely because it is aware of the radical difference between the unredeemed world of history and that of the Messianic redemption (Scholem 1971, 16). 
Said's critical efforts are on the whole geared towards exposing the lingering and pervasive influences of Christian notions of redemption on the supposedly secular West; nowhere does he admit that the very idea of the secular that he employs is at root Christian itself, neither does he allow for the possibility of a religious tradition that itself might cast shadows of doubt over the legitimacy of a project of national founding. Scholem's letter captures well the horror of a religious Jew, himself a Zionist, recoiling from the moment whereby the language of God is shorn of its sacred context and usurped by man for the utilitarian purposes of everyday speech. So while Said's 'secular criticism' may well still be relevant as a tool for exposing a movement entrenched in the identity politics that he seeks to deconstruct, one perhaps engaged in 'religious thinking' in the Saidian sense, his objections to Walzer's use of Exodus lacks a nuanced awareness of Judaism as Jewish culture. As Hart writes, 'we begin where we are with the resources at hand, including religious narratives' (Hart 2000, 7).

Interestingly, Walzer too, in spite of his admission of the need to engage with the Jewish religious tradition, entertains a notion of secularism indicating 'religionabolished' as does Said. Walzer is careful to distinguish his version of 'Exodus politics' from religious messianism, which he sees as plaguing the politics of right wing Zionists whose views, he believes, are largely aberrant to the movement. One might here agree with Said's conclusion that Walzer's book is more the product of a political agenda than an interrogation into the philosophical issues to which it gives rise. Scholem's letter speaks eloquently to Walzer's simplification of the relationship between Zionism and messianism.

Scholem is on the one hand, according to Joseph Dan, concerned to demonstrate that

\footnotetext{
'Zionism is an 'existential' movement, rebelling against the futility of historical activity in an unredeemed world, claiming that historical achievements can be brought forth without any transcendent intervention and without waiting for one or depending on one. Zionism, according to his concept, is a complete departure from all conflicting views and attitudes of Jewish messianism put together: it rebels against the demand to wait for divine redemption, and it refuses to see itself as the culmination of one' (Dan 1992, 126).
}

And yet on the other hand, as Derrida points out, 'Scholem acknowledges that Messianism aims at the "re-establishment of a lost [historical] reality”, even though 
"it went beyond that”". Thus in his letter to Rosenzweig, Scholem presents secularisation both as a risk run by Zionism and as an actual impossibility: secularisation 'is only a facon de parler', 'a ready-made phrase'. Thus, as Derrida suggests, 'it is a secularisation that allows us to speak of a secularisation that does not take place.' Haunted by the possibility of the impossible, Hebrew is therefore potentially a 'language that turns against those who speak it' (Grossman 1999, 210), one which incorporates the logic of vengeance and assigns a responsibility which ‘exceeds individual responsibility'. Scholem's letter thus reads as a warning to future generations who will have to make sense and re-signify the explosive 'tradition' - one stalked by the threat of secularisation on the one hand and an 'eruption of the 'sacred' on the other - that is their inheritance (Derrida 2002, p189-228).

Scholem thus portrays Zionism as an impossibly secularised messianism. It is essential that it be distinguished from Jewish religious - and messianic - traditions, yet it inevitably runs with them in the same stream. This unavoidable paradox renders Walzer's project of secularisation naïve as Said's secularism is so often blind. Moving from the debate on Exodus between a Jewish American and a Palestinian American, this paper will now attempt to trace the movements of exodus at work in the writings of Israeli author David Grossman, whose Hebrew narratives take on the very threat of secularisation that Scholem so vividly depicted, narratives which illustrate Scholem's powerful metaphor for the nation: 'This country is a volcano' (Scholem quoted in Derrida 2002, 226).

\section{David Grossman: negotiating Diaspora and the promised land}

'This country is a volcano. It houses language. One speaks here of many things that could make us fail. One speaks more than ever today about the Arabs. But more uncanny than the Arab people another threat confronts us that is a necessary consequence of the Zionist undertaking: What about the "actualizaton” of Hebrew? Must not this abyss of a sacred language handed down to our children break out again?' (Scholem quoted in Derrida 2002, 226) Grossman’s Hebrew novel See Under: Love speaks to this warning of Scholem's in that he dramatizes the 'burden' placed on future Israeli generations in explicitly linguistic terms. 
Grossman's text is specifically concerned with Israel as a destination of escape from the horrors of the Holocaust. First and foremost Israel emerges as a site onto which a new conception of Jewish 'destiny' may be mapped through an alternative sign system from that which was available in Europe. Grossman thus portrays a flight from the tyranny of instrumentalized language, from 'the first person plural, where one is weighted on scales: "My Jew for your Jew”; “According to my calculations, I killed only two and a half million," etc' (Grossman 1999, 165). Against the brutal reality of deportation to the death camps that lurks behind Nazi euphemisms such as 'exodus or migration’ (Grossman 1999, 284), Grossman’s characters envisage a different kind of escape: 'I don't mean in the usual sense of the word, but in the special sense... someone who crosses the prescribed and generally accepted borders and brings himself into the magnetic field of a different dimension of existence, travelling light...' (Grossman 1999, 100).

Thus Bruno metamorphizes into a creature of the sea and escapes the fate of European Jewry by becoming an artist and 'fertilizing language' in order to illustrate that 'the truly crucial things had to be said in the singular’ (Grossman 1999, 165-166). Similarly, Anshel Wasserman becomes 'a fugitive from human language in order to protect himself from all the words that cut his flesh' (Grossman 1999, 283). He is the Jew that cannot die, and against the logic of Neigel, the Nazi officer to whom Wasserman tells his story, he does ‘wage a war with words’ (Grossman 1999, 285), one that exceeds the power of Neigel's gun that would make him stop. Wasserman's and Bruno’s experimentation in narrative therefore interrupts the economy of intentionalized speech, 'a language that will admit a sentence like "I killed your Jew... In that case, I will now kill yours”, etc.'(Grossman 1999, 168).

In plumbing the depths of the sea, Bruno’s ‘escape strategy' attempts to find a new way of reading, one which recognizes that 'there are deeper abysses than we can possibly conceive of' (Grossman 1999, 133). Evading the issues faced by Momik in the novel such as 'how to be a real Jew', Bruno instead loses his identity in 'the vastness of the sea, the joy of life, compassion and communion, and defiance and knowledge of impotence’ (Grossman 1999, 130). In giving himself over to linguistic indeterminacy, in 'murdering' conventional linguistic meaning in order to give 
language new life, both Bruno and Wasserman recognize their responsibility to language, a responsibility that becomes inseparable from questions of faith.

For against the calculating and brutalized 'rationality' exemplified by the Nazis, these storytellers demonstrate that the enormity of the Holocaust exceeds the human desire to render it meaningful, to capture it through representation. 'While other tragedies can be translated into the language of reality as we know it, the Holocaust cannot, despite the compulsion to try again and again' (Grossman 1999, 124). The significance of the Nazi crime against humanity exceeds the significance of the Nazis themselves, thus constituting a transgression in the face of Being - Being here suggesting a plurality that constitutes something greater than, and not reducible to, individual beings. So in a sense, Grossman's characters re-establish their place in the correct order of things by self-consciously wrestling with a language whose authority overreaches their own. This metaphor of wrestling recalls the Hebraic tradition of the covenantal responsibility, of 'the paradigmatic portrait of God wrestling with his people in every generation, always ensuring that his promises continue from generation to generation’ (Dennis Olson quoted in Zornberg 1995, 91).

This promise is sealed in the endless possibilities of the future to which language must address itself. See Under: Love almost mimes a midrashic search for meaning in which the definitions it seeks constantly gesture beyond themselves. Thus the novel moves away from the subject-centred sense of reality that is one of Christianity's defining features - what Susan Handelman describes as 'the theology of silence' (Handelman 1982, 5) - towards a tradition that has always located divinity in the text. In this sense, then, it is possible to locate Grossman's work in the specifically Jewish religious tradition that was discussed above. 'God' emerges a principal character in the world of the novel - for while Grossman describes himself as a secular Jew, the question of the divine is as inescapable for him when negotiating his Jewish identity as it is for his protagonists.

The characters that populate See Under: Love are constantly addressing themselves to God: 'O Lord, said Bruno (who had never been religious), to what end do you impel these millions of salmon in endless circles around the world?' (Grossman 1999, 128). Hannah pleads ‘God, God, how long must I wait for you, God’ (Grossman 1999, 73) 
and throughout the novel she attempts to 'seduce' him. The seduction metaphor is suggestive of the temptations that much of the Judaic tradition seeks to guard against: the human desire to usurp the power of God by acting in his name. Unlike in the Christian tradition, Jews were not meant to 'act as if God had abandoned them'. God may be seduced but it is his human agents who must consistently assume responsibility for the consequences of this: it is the Jews that have been 'chosen' to meet the challenge of a dialogue with - and directed by - God.

See Under: Love therefore exemplifies the crossovers between postmodernist discourses on the text and Jewish thinking on language. This notion of God as the invisible yet ever-present addressee of speech is essentially deconstructive, rendering all human action as provisional and open to what is other. Responsivity to the constant and perennial call of futurity is thus responsibility to the relational. Hence in the novel Wasserman claims that decisions are never permanently valid and call for reaffirmation each time the decision is acted upon. Neigel's horror at this proposal perhaps demonstrates its potentially radical nature as well as the validity of what becomes one of the central refrains of the novel: the idea that 'you don't "start” to do evil, you only continue doing it' (Grossman 1999, 296). This deconstructive sense of the need for continual revision recalls Derrida’s ‘dredging machine’(Derrida 1986, 204). And indeed the name of 'God' has been explicitly invoked by Derrida in his more recent writings as one of the names, along with 'justice', 'responsibility', the 'other' etc, that act as an interruptive force on the present. This specifically Jewish notion of the messianic, the variant that holds self-identity in abeyance, has thus been a major influence, perhaps the major influence - via the work of Derrida and before him Levinas - on what can very generally be described as ‘ethical postmodernism'. I use this very vague term in contradistinction to the celebratory - or indeed pessimistic - theories of postmodernism that act as diagnosis for the contemporary world as opposed to those that seek to re-think it with an eye to change.

These often noted connections between Jewish thought and postmodernism have led some theorists to suggest that Jewish identity is paradigmatic for the sense of homelessness that pervades the postmodern world. Thus Susan Handelman writes: 'the "play of difference" advocated by Derrida is the torment of the Christian thinker, the unacceptable exile.' The Jews, on the other hand, 'are so strangely at home in 
exile, in the play of signs, in the wanderings of figurative language, and in their own constant physical wanderings’ (Handelman 1982, 120). Jonathan and Daniel Boyarin go as far as to invoke the metaphor of Jewish male circumcision as a symbol of “connection by separation”. They name the foreskin as “supplement” and claim that Judaic theories on circumcision exemplify a "sensibility [that] resonates with the poststructuralist critique of the modern image of a dematerialised human subject" (Boyarin \& Boyarin 1994, 23-26). There is a leap being made here between traditions in Jewish thinking and the practical experience of being Jewish. David Gunkel, in a paper discussing Exodus, describes the force behind much postmodernist thinking as an 'escape velocity', for, he writes, there is a 'curious association between the postmodern and liberation' (Gunkel 1998, 237). Seen in this light, then, Handelman's and the Boyarins' comments imply that the Jews have perhaps uniquely managed to escape the trappings of identity that plague the contemporary world. Forced to experience home as alienation, the Jews' physical conditions have followed the path first laid down by God's command of 'lekh lekha' in the Hebrew Bible.

And yet, returning to Grossman's text, this dialogue with God for which the Jews have seemingly been singled out threatens throughout the novel to break down. In fact, while the Jewish notion of God actualized in social space is continually assumed by the protagonists in the novel that try to address him, there is a sense that their appeals to him are futile. 'Mrs Zeitrin is... angry with God' (Grossman 1999, 15), suggesting that although he may not have abandoned her, he certainly has let her down. The text thus expresses the perhaps failed attempt to reassemble the fragments of a tradition, one based on faith in God, in meaning, in the aftermath of the Holocaust. The possibility of the ‘absence of an addressee' (Sicher 1998, 20) lurks behind every word. While as Effriam Sicher suggests, the necessity to remember and repeat the experience of the Holocaust mimics the injunction to continue telling the story of the exodus from Egypt (Sicher 1998, 23), it may be that while the latter confers a shape to the notion of freedom, and of language as responsibility to this freedom, the former runs the risk of the negation of meaning in language.

So while See Under: Love highlights some of the theoretical similarities between postmodernist and Jewish thinking on language and identity, it also underscores the historical event that perhaps confirmed the connection between the two and which in 
fact considerably complicates the casual slippage between 'postmodern' and Jewish notions of identity. The event of the Holocaust acts as a potent symbol of a world seemingly bereft of moral coordinates that is the hallmark of pessimistic theories of the postmodern. The image of the Jews led to be massacred by the Nazis 'like lambs to the slaughter' becomes a synecdoche of a world with no logic, meaning, or means to map itself. The experience of the Holocaust lent painful imagery to the Jewish tradition of religious passivity, and Grossman's novel is suffused with portraits of waiting, and of the often helpless sense that 'only God can help... God help us' (Grossman 1999, 76). For as Scholem explains, 'in Judaism the Messianic idea has compelled a life lived in deferment, in which nothing can be done definitively, nothing can be irrevocably accomplished'. The very trend in Judaism - that is, Messianism that links Jewish thinking to that of the postmodern 'corresponds', writes Scholem, 'to the endless powerlessness in Jewish history during all the centuries of exile, when it was unprepared to come forward onto the plane of world history’ (Scholem 1971, 36).

Thus thinkers like Handelman who imply that the Jews are somehow 'happy' with the condition of exile that has been forced upon them shy away from the fact of the state of Israel's rise, the existence of which was secured by the brutal event that defined the Second World War. As Scholem sees it, the Jewish return to Zion was motivated by the 'enticement to fulfilment' dormant in messianism and activated by the utopian elements coexisting with it. Intimately connected with the messianic hope then, Zionism nonetheless broke with it by moving onto the historical plane and bringing about 'irrevocable action in the concrete realm'. Zionism's relationship with messianism is therefore much more entangled than Walzer would have it. Yet Zionism 'has not given itself up totally to Messianism' (Scholem 1971, 36). The conflation of notions of Jewish - ethnic - identity with the anti-essentialist identities promoted by postmodernism is a suspect move even when the emphasis is on the diasporic consciousness of Jews living in exile. It becomes even more tenuous when speaking of Zionist notions of Jewish identity that embody a logic decidedly in opposition to Diaspora. This is precisely the move made by Grossman in some of his non-fiction writing, as I will attempt to show below.

In See Under: Love Momik’s attempt to tame the 'Nazi beast' represents his own impulse to evade self-definition by the Jewish experience of Diaspora. The crushing 
burden of his parents' expectations of him lead Momik to scorn their generation who have 'never done anything in their lives to fight back, they just sit there bickering about those stories no one gives a damn about' (Grossman 1999, 83). And yet his desire for exodus from the past does not lead him to seek the kind of borderless freedom realized by Bruno in the sea. While the underwater population propels itself 'ever onward, wandering homeless', Momik pines for the security of place offered by the promise of solid grounds. As his reaction to the 'Messiah' episode reveals, he 'loves' his 'fetters' and does not want to answer the Messiah, 'the one who calls us to freedom'. The 'final conclusion' offered by the Messiah is one in which all trappings of self-understanding fall away, and while this ultimate loss of identity is proffered as 'the big secret', the 'truth', Momik rejects this chaotic version of reality, claiming that 'some of us need orderly framework, law, to continue.' (Grossman 1999, 166 - 184).

The Messiah episode outlines the cruelty inherent in the denial of human selfdefinition, and it in many ways seems to be Grossman's confirmation that the Jewish desire for self-determination does not dovetail with messianism, it is rather a legitimate deviation from it. And yet writing elsewhere, he seems to suggest otherwise. In his introduction to an edition of Exodus, Grossman vividly depicts this anxious tension in Jewish identity between the figures of Diaspora and homeland. He juxtaposes the Jewish 'taste for wandering' with 'an intense longing for a 'promised land'” and evokes the paradox of 'freedom' which seemingly calls from both directions (Grossman 1998, xii). Like Walzer, Grossman draws on the Exodus narrative as an allegory for the foundation of the state of Israel and the movement from which it was founded. But Exodus becomes more for Grossman in this piece than simply a founding cultural myth. The 'tortured existence' of the Israelites of 'Exodus’ becomes ‘a “history” and a religion’ (Grossman 1998, x). While ‘history’ is placed in quotation marks, he does nonetheless trace his 'forefathers' to 'the children of Israel' while modern Israeli Jerusalem is named 'the promised land’ (Grossman 1998, viii). Given Grossman’s position as a critic of Israeli treatment of the displaced Palestinian population, it is perhaps surprising that he deploys such controversial tropes with such apparent ease.

The journey of the Jews to Israel is thus configured by Grossman as a postcolonial 'return', and the 'history' of Exodus lends a 'unique status' to 'the Jewish people', 
who are particularly 'vulnerable to tragedy in a world that is all definition and borders’ (Grossman 1998, xvi). While Grossman seems concerned in See Under: Love to portray Israeli self-determination as a protestation against an enforced homelessness, in this piece on Exodus he manages to portray 'wandering' as a 'national end in itself' (Grossman 1998, xiii) for the Jewish people, making no attempt to distinguish these people from those now firmly lodged in a Jewish national home. While few would dispute the vulnerability of the location of contemporary Israelis, the 'definition and borders' which currently threaten them are of their own making and cannot be compared to those which threatened their destruction in Europe. This slippage between the two masks a contradiction. Grossman would like to have it both ways: that the Jewish propensity to a 'life lived in deferment' is maintained in the historically realized promised land. But the Jewish religious safeguard against the dangers of fulfilment - vividly illustrated by Moses’ dying glimpse of the promised land - cannot be seamlessly extended to encompass the decidedly realized dream of the Jewish state. The Israeli conflict with the Palestinians cannot write itself into the narrative of 'the tragedy of Jewish fate' (Grossman 1988, 218).

This contradiction, I would argue, is not simply glossed over in See Under: Love literature perhaps being a medium better able to maintain what are often mutually exclusive alternatives. So while in his piece on Exodus, Grossman describes the Israeli 'national character' as being drawn through the crucible of 'victimhood' and fails to note - while in many ways exemplifying - the attendant dangers of this, his novel displays an acute awareness of them. Thus Momik, who describes himself as 'a regular Holocaust homing pidgeon’ (Grossman 1999, 151), is told by Ruth that he needs to 'admit it isn't the gas chamber every time somebody swears at you at an intersection' (Grossman 1999, 136). Although this is clearly making a very large leap, this comment can perhaps be connected to Jacqueline Rose's claim about the need to differentiate the debris resulting from Palestinian suicide bombings and that which came from the Nazi death camps (Rose 1996). In the novel, Fried, who has been 'battered' by life lives it as if it were 'his booty' (Grossman 1999, 354). Again, perhaps, the connection can be made with another statement by Rose: 'trauma, far from generating freedom, openness to others as well as to the divided and unresolved fragments of a self, leads to a very different kind of fragmentation - one which is, in 
Freud's own words, “devastating”, and causes identities to batten down, to go exactly the other way: towards dogma, the dangers of coercive and coercing forms of faith’ (Rose in Said 2003, 76).

These allusions to the dogmatism inherent in some forms of faith recall Edward Said - this is no coincidence as Rose here is responding to his lecture on 'Freud and the non-European'. In his introduction to the Hebrew edition of Totems and Taboo, Freud famously described himself as 'ignorant of the language of holy writ', 'completely estranged from the religion of his fathers' and unable to 'take a share in nationalist ideas' (Freud quoted in Said 2003, 70-71). He then suggests that perhaps, therefore, he represents the very 'essence' of Jewish identity. Said's interpretation of Freud latches onto this non-essential essence to speak about how Freud opens up Jewish identity to its non-Jewish beginnings by emphasizing the Egyptian origin of Moses. Said claims that Freud 'mobilized the non-European past in order to undermine any doctrinal attempt that might be made to put Jewish identity on a sound foundational basis, whether religious or secular' (Said 2003, 45). Rose's critique of Said presents an interesting scenario in which she cautions one of the principle spokespersons for the Palestinian cause against unqualified invocations of a trend in Jewish thinking running through Zionist discourse that has the effect of suppressing the Palestinian narrative: the idea that it is somehow 'the task of Jewish particularity to universalise itself' (Rose in Said 2003, 72). The irony of the situation is compounded by the fact that Rose here is reminding Said, the vocal critic of the 'religious' dogmatism at the heart of identity politics, that an emphasis on the 'irremediably diasporic, unhoused character' (Said 2003, 53) of Jewish identity can congeal into an - ultimately unhelpful - article of unexamined faith.

Rose offers a corrective to Said by saying 'we should see Freud less as purely the diagnostician of - more squarely inside - the dilemma of identity which he describes' (Rose in Said 2003, 74), This, of course, is the same dilemma faced by all of the writers discussed in this paper: that their critical insights into identity are considerably tempered by their own personal investments in the collective sense of self. So just as Wasserman wrests the 'permission' to 'continue the story' (Grossman 1999, 287) from the Nazi officer Neigel who has played a role in actively suppressing it, and Grossman thus voices his vision of Jewish identity, Said demands 'the permission to 
narrate’ (Said 2000a, 243) Palestinian identity from those who would have it silenced. In this move his advocated critical mode of the 'exilic consciousness' is granted the right to contemplate the object of 'home'. This then surely transgresses the contours of the irremediably exiled character by which 'secular criticism' defines itself?

What emerges as appealing in Said is that he never succumbs to the temptation to mask over the contradictions in his thinking. While he fails to admit that his insistence on an identity politics for the Palestinians does not remain true to his promotion of nomadic, anti-essentialist self-definition, nowhere is reconciliation attempted. These tensions stand out as glaring and thus productive while those in Grossman, as I have tried to show above, require illumination. Touching on the question of Zionism, Said's 'secular criticism' begins to dissemble, and yet it is this very process that shows the name of 'God' to be both everywhere and nowhere in the discursive field of Jewish identity.

\section{Conclusion: the trauma of chosenness}

Through linking Jewish identity to the archetypal self envisioned by discourses of the 'post', theorists take up 'the task of Jewish particularity to universalise itself'. This move needs to be questioned, particularly when deployed in discussions of Zionism for which it can often become an apology. In the same vein Said questions Walzer's use of Exodus as a vehicle with which to merge the religious and the historical. Said therefore objects to the move made by Walzer when he describes the cruelties to which the Hebrews were afflicted as 'the first of a series of attempts on Jewish peoplehood that culminated in the Nazi death camps' (Walzer 1985, 26). Walzer’s connection here is part of a wider and to some degree understandable tendency to link the historical traumas suffered by the Jewish people to the religious burden of having been chosen by God - a tendency exposed and refuted in Grossman's See Under: Love. As suggested above, the Jewish tradition is more vulnerable to this confusion than most. Hence Said's approach is helpful in unravelling such textual complicities, yet not necessarily, as he would have it, to guard the secular from the sacred, but rather, and often, to preserve the integrity of what Derrida names the religious 'scruple'. For as Scholem puts it, the decision inherent in Zionism, for better or worse, removed the Jewish people from the nebulous realm of 'meta-history' and consigned 
them to the planes of 'history' (Scholem 1971, 36). That history, then, offers itself up to judgement and cannot claim exemption via notions of Jewish exceptionalism.

Ahad Ha-Am wrote: 'every true Jew, be he orthodox or liberal, feels in the depths of his being that there is something in the spirit of his people - though we do not know what it is - which has prevented us from following the rest of the world along the beaten path' (Ahad Ha-Am quoted in Said 2003, 43). As this paper has tried to argue, one of the distinguishing marks of Jewish identity is the unique locus of religion within Jewish culture. If, as Freud claims, trauma is what binds a common people, then in the case of the Jewish tradition, a distinct religious identity is intimately tied to this trauma. It is not surprising, therefore, that Jewish suffering - in history - and consequent means of redemption - again, in history - should take on the status of a sacred text. Nowhere is this link better dramatized than in the Exodus story, where the traumatic denial of 'home' and the subsequent search in the desert occasions a special election by God.

That this notion of chosenness has become bound up in the traumatic history of the Jews has seriously problematized the position of the 'victims of the victims' to the point where many are actually 'blaming the victims' (Said 1988). There is almost a perception that the Jews, chosen by God to suffer themselves, cannot therefore inflict suffering on others. When Michael Walzer rejects Said's notion of secular criticism as that of the minority, he states: 'even the oppressed need their critics' (Walzer in Hart 2000, 193). This claim could very easily have come from the opposite direction: the Palestinian right to self-determination buckles under the shadow of the persecuted past of the Diaspora Jew. As Joe Cleary writes, 'Palestinian suffering is always measured in the scales with Jewish suffering in the Diaspora' (Cleary 2002, 170).

Said's notion of 'minority' criticism as secular stems from an uneasy coalescence within his thinking of postmodernist visions of exiled consciousness tempered by a strong dose of Marxian materialism. Thus the condition of exile often rendered universal by postmodernism is particularized in Said, who wants to hang on to the very distinct and real difference between states of mind and those of the body. This tension in Said's thinking creates an interesting dialogue with the contradictions inherent to Grossman's work: both writers identify the secular as a point of reference 
but have a tendency to leave it behind when their eyes fixate on the image of homecoming. The groundlessness negotiated by them in their complex encounters with postmodernism both solidify and disintegrate the image of land which neither is ultimately willing to relinquish.

Postmodernist discourses which wish to theorize identity politics out of existence often tend - in their attempts to avoid over-valuing their object of critique - to undervalue it and thus ride over these material differences so important to Said. Said thus advocates a constant reassessment of those conditions in the interests of the minority. His method is deconstructive yet it maintains a fully recognisable and to some degree intending human subject as its motivating force. And herein lies the major divergence between Said and Grossman: Grossman’s work slides neatly into the postmodern critique of humanism and his version of Israeli identity politics is universalised under the aegis of a 'wandering' (read: exiled, postmodern) nation; Said's projection of Palestinian identity politics relies on the notion of agency and thus remains susceptible to accusations of ‘essentialism’ which Grossman’s construction, somewhat problematically, attempts to bypass.

Given Said's sense of the need to maintain the idea of human agency in the face of the postmodernist attack, it is unsurprising that the focus of his own attack on Zionism does not hinge on the activist aspirations of the Jewish national movement. Yet in the light of Said's attendant emphasis on the need for critical distance and an alienated consciousness when acting as spokesperson, it seems that in many ways Judaism might act in relationship to Zionism as just this 'scruple', this potentially critical and disruptive force that might undermine a culture from within. Judaism could harbour within itself that very deconstructive mechanism which might prevent the act of escape from rebounding on itself and recreating those very conditions from which it sprung.

The Zionist movement ran into this fact by founding the Jewish state on the basis of the very ethnic oppression that they wished to leave behind in the Diaspora. The state of Israel is in many ways thus a monument to the anxieties inherent to Judaism surrounding the corruption of power and the potential corruption of religion if it ever came to be identified with that power. Just as Rabbi Kook remained sceptical 'about 
the desirability of the Jews gaining political power so long as the world is not redeemed' (Avineri 1981, 197) - in spite of his fierce support for Zionism - so Ben Gurion confirmed his fears, telling Yeshayahu Lebowitz 'I will never agree to the separation of religion from the State. I want the State to hold religion in the palm of its hand' (Ben Gurion quoted in Leibowitz 1992, 115). In See Under: Love Neigel mocks the 'Jewish God' who would disallow the rebuilding of the second temple because the king had blood on his hands (Grossman 1999, 406). This is the kind of 'God' Udi Aloni imagines when he describes ‘the transience and the responsibility that is in the secular' (Aloni 2004, 97). This deconstructive sense of the sacred gestures towards messianic time and aspires to a transformed vision of the world not dissimilar to that encapsulated in the Saidian notion of 'secular criticism'. This notion embodies a much more complex sense of the secular than Said will admit, one which ricochets between the sites of home and alienation, the secular and the sacred, human agency and a postmodern maze of an always already determined world. Just as Leibowitz portrays 'chosenness' as a goal rather than a gift, Saidian criticism aspires towards and constantly reinvents what it might mean to truly achieve exodus.

\section{Reference List}

Aloni, U., 2004, Local Angel: Theological Political Fragments, trans. Howard Cohen, ICA, London.

Avineri, S., 1981, The Making of Modern Zionism: The Intellectual Origins of the Jewish State, Weidenfeld and Nicholson, London.

Bayoumi, M \& A. Rubin, A (eds.), The Edward Said Reader, Granta, London. Boyarin, D. \& J, Boyarin, 1995, 'The Double Mark of the Jew', Rhetorics of Self Making, ed. D. Battaglia, University of California Press, Berkley.

Budick, S. \& G. Hartman, (ed.), 1986, Midrash and Literature, Yale University Press, New Haven \& London.

Caputo, J.D., 1997, The Prayers and Tears of Jacques Derrida, Indiana University Press, Bloomington \& Indianapolis.

Cleary, J., 2002, Literature, Partition and the Nation State, Cambridge University Press, Cambridge.

Cohen, J., 1990, Voices of Israel, State University of New York Press, Albany.

Dan, J., 1992, 'Scholem’s View of Jewish Messianism' in Modern Judaism, vol.2, 119-126.

Derrida, J., 1986, Glas, trans. J P Leavey, Jr, \& R Rand,University of Nebraska Press, Lincoln \& London.

- 2002, Acts of Religion, Routledge, New York \& London.

Dooley, M., 2001, The Politics of Exodus, Fordham University Press, New York. Grossman, D., 1988, The Yellow Wind, trans. Haim Watzman, Picador, New York.

- (ed.) 1998, The Second Book of Moses, called Exodus, authorised King James Version with an introduction by David Grossman, Canongate, Edinburgh. 
1999, See Under: Love, trans. Betty Rosenberg, Vintage, London.

Gunkel, D., 1998, 'Escape Velocity: Exodus and Postmodernism', Soundings, vol. 81, no.3-4: 437-459.

Handelman, S., 1982, The Slayers of Moses, University of New York Press, Albany.

Hart, W., 2000, Edward Said and the Religious Effects of Culture, Cambridge University Press, Cambridge.

Leibowitz, Y., 1992, Judaism, Human Values, and the Jewish State, trans. Eliezer Goldman, Harvard University Press, Cambridge Massachusetts \& London.

Rose, J., 1996, States of Fantasy, Oxford University Press, Oxford \& New York.

Said, E., 1983, The World, the Text, and the Critic, Harvard University Press, Cambridge Massachusetts

1988, 'Michael Walzer's Exodus and Revolution: A Caananite Reading', in Blaming the Victims: Spurious Scholarship and the Palestinian Question, eds. C Hitchen \& Edward Said, Verso, London \& New York 2000, Reflections on Exile, Granta Books, London. 2003, Freud and the Non-European, Verso, London \& New York.

Scholem, G., 1971, The Messianic Idea in Judaism Shocken Books, New York

Shlaim, A., 2000, The Iron Wall, Penguin Books, London \& New York

Sicher, E., (ed.), 1998, Breaking Crystal: Writing and Memory after Auschwitz, University of Illinois Press, Urbana \& Chicago.

Walzer, M., 1985, Exodus and Revolution, Basic Books, New York.

Zornberg, A. G., 1996, Genesis: The Beginning of Desire, The Jewish Publication Society, Jerusalem \& Philedelphia. 